\title{
PRAKTIK INFORMASI SEBAGAI UPAYA PROPAGANDA PROGRAM KOLONISASI PADA MASA HINDIA BELANDA
}

\author{
Purwanto Putra ${ }^{1^{*}}$ \\ ${ }^{1}$ Pengajar Prodi D3 Perpustakaan Jurusan Komunikasi FISIP Universitas Lampung \\ *Korespondensi: purwanto.putra@ fisip.unila.ac.id
}

\begin{abstract}
ABSTRAK
Tulisan ini membahas tentang praktik informasi sebagai propaganda Pemerintah Hindia Belanda berkaitan dengan upaya mensukseskan pelaksanaan program kolonisasi sebagai dampak dari kebijakan politik etis yang mulai diterapkan pada tahun 1905 hingga 1942. Penelitian ini menggunakan studi pustaka dengan mendalami arsip-arsip dan literature sekunder kolonial Belanda. Dari hasil penelitian menunjukkan bahwa Pemerintahan Hindia Belanda ketika itu menerapkan beberapa strategi informasi untuk memotivasi masyarakat agar mengikuti kolonisasi, berpindah dari pulau Jaw a menuju pulau -pulau lain. Setidaknya ada dua strategi utama yang diurakain secara lengkap dalam penelitian ini yaitu propaganda dengan menerapkan strategi informasi secara langsung dan strategi informasi tidak langsung. Temuan lainnya juga menjelaskan bahwa secara garis besar strategi informasi yang diterapkan pemerintah Hindia juga memuat berbagai inovasi yang membawa keberhasilan. Kondisi yang juga menarik adalah bahwa dari praktik informasi yang diterapkan pada masa itu tergolong sangat membebani karena membutuhkan pembiayaan yang sangat besar. Hal itu dikarenakan kondisi masyarakat pulau Jawa yang sebagian besar belum dapat membaca dan menulis.
\end{abstract}

Kata kunci: Kebijakan informasi, propaganda, kolonisasi

\section{PENDAHULUAN}

Pada masa-masa awal abad ke-20 Ratu Belanda, Wilhelmina, sudah berencana untuk menerapkan suatu kebijakan politik etis di Hindia Belanda. Politik etis yang mulai diterapkan pada tahun 1900 bertujuan mensejahterakan masyarakat petani yang telah dieksploitasi selama dilaksanakannya culture stelsel (sistem tanam paksa). Karena sistem tanam paksa tersebut secara empiris telah menyebabkan orang-orang pribumi semakin menderita. Dari sisi ekonomi, tanam paksa telah menyebabkan pula berubahnya sistem perekonomian tradisional ke arah pola perekonomian baru (dualisme ekonomi), dan bertambah miskinnya penduduk -terutama masyarakat petani.

Kondisi tersebut akhirnya menggugah para birokrat dan kaum etis Belanda seperti C. Th. van Deventer seorang ahli hukum sekaligus anggota parlemen Belanda yang mengkritisi kebijakan pemerintah, kritiknya seperti tertuang dalam sebuah tulisan bertajuk Een eereschuld, 
"A Debt of Honor" atau dapat diartikan sebagai suatu hutang kehormatan yang dimuat pada jurnal de Gids. Van Deventer dalam artikelnya membuat suatu rekomendasi agar pemerintah Belanda memberi bantuan dalam rangka mensejahterakan penduduk di daerah jajahannya yang mana pada kenyataanya juga telah banyak memberikan keuntungan pada pemerintah Belanda atas kebijakan sistem tanam paksa.

Bangsa Belanda selama ini sangat berhutang budi kepada tanah Hindia (Indonesia) atas semua kekayaan sumber daya yang telah didapatkan. Untuk itu, kesejahteraan rakyat di Hindia merupakan hal yang harus dijadikan prioritas utama. Selanjutnya, sebagai rasa tanggung jawab moral pemerintah Belanda, tahun 1902, Gubernur Jendral Idenburg mulai menerapkan kebijakan politik etis di Hindia bagi para penduduk nusantara sebagai upaya untuk meningkatkan kesejahteraan masyarakat pribumi yang mencakup tiga program yaitu (1) emigrasi, (2) irigasi, dan (3) edukasi

Kebijakan kolonisasi penduduk dari pulau Jawa ke luar Jawa secara umum dilatarbelakangi oleh tiga hal. Pertama, melaksanakan salah satu program politik etis, yaitu emigrasi untuk mengurangi jumlah penduduk pulau Jawa dan memperbaiki taraf kehidupan yang masih rendah. Kedua, pemilikan tanah yang makin sempit di pulau Jawa akibat pertambahan penduduk yang cepat telah menyebabkan taraf hidup masyarakat di pulau Jawa semakin menurun. Dan ketiga, karena adanya kebutuhan pemerintah kolonial Hindia Belanda dan perusahaan swasta akan tenaga kerja di daerah-daerah perkebunan dan pertambangan di luar pulau Jawa.

Secara lebih khusus berkaitan dengan bidang migrasi, pemerintah kolonial Belanda berupaya untuk mengadakan redistribusi penduduk dari pulau Jawa ke luar Jawa. Pil ihan ini diambil sebagai alasan rasional karena kondisi pulau Jawa yang terlalu padat penduduknya. Ada begitu banyak penjelasan tentang bagaimana padatnya penduduk di pulau Jawa. Menurut pemikiran Mohr, seorang ahli geologi dan tanah berkebangsaan Belanda, kepadatan penduduk di pulau Jawa disebabkan keadaan tanah yang subur serta iklim yang menguntungkan bagi pertanian. Pendapat lain seperti juga yang disampaikan oleh Fisher, ahli geografi berkebangsaan Inggris, tentang adanya ketimpangan distribusi penduduk antara pulau Jawa dan luar Jawa yang disebabkan oleh kebijakan pemerintah Belanda yang terlampau Jawa sentris, sehingga pembangunan atas pusat-pusat pertumbuhan seperti pendidikan, perdagangan, pemerintahan, dan juga prasarana transportasi, komunikasi, dan irigasi lebih terkonsentrasi di pulau Jawa. 
Hal ini berlanjut pada kritik terhadap kebijakan tanam paksa yang turut menyuburkan kemiskinan sebagai cikal bakal lahirnya politik etis atau politik balas budi. Politik balas budi dijalankan pemerintah kolonial melalui tiga program pokok, yaitu edukasi, irigasi dan emigrasi. Pemerintah Hindia Belanda yang percaya bahwa pulau Jawa telah padat penduduknya akhirnya membiayai dan menyelenggarakan pemindahan penduduk dari pulau Jawa ke pulau Sumatera, suatu program yang kemudian diberi nama kolonisasi. Kolonisasi ditujukan terutama untuk memenuhi kebutuhan buruh murah perkebunan-perkebunan swasta Belanda di daerah luar Jawa, terutama di selatan Sumatera. Di utara Sumatera pengerahan tenaga kerjanya dilakukan melalu i kuli kontrak, di selatan Sumatera melalui kolonisasi.

Sehubungan dengan rumusan di atas, maka pertanyaan penelitian yang ingin dijawab adalah Bagaimana kebijakan informasi dan propaganda yang dijalankan pemerintah Belanda dalam mendukung pelaksanaan kolonisasi di Hindia Belanda ketika kebijakan politik etis diterapkan? Informasi dan propaganda yang dimaksud disini adalah apa saja bentuk dan produk yang dikeluarkan Pemerintah Hindia Belanda. Siapa yang menjalankan kebijakan informasi dan propaganda tersebut. Seberapa besarkah dampak kebijakan informasi dan propaganda terhadap kelangsungan program. Bagaimana respon kolonis dalam menerima kebijakan dan propaganda tersebut.

Dalam konteks ilmu informasi dan perpustakaan penelitian dengan latar sejarah ini sangat penting kiranya untuk diketengahkan. Disamping untuk mengetahui kondisi nyata tentang praktik informasi pada program kolonisasi masa pemerintahan Hindia Belanda. Penelitian ini juga dapat mengungkapkan bagaimana kondisi dan kekhasan praktik informasi pada masa Hindia Belanda untuk diperbandingkan dengan masa sekarang. Perkembangan budaya dan teknologi disinyalir akan memberikan perbedaan-perbedaan situasi antara masa sekarang dengan masa lampau. Tulisan ini diharapkan akan membawa dampak secara signifikan pada perkembangan cakupan penelitian bidang informasi dan perpustakaan serta menjadi semangat dan kesegaran baru bagi penelitian-penelitian ilmu informasi dan perpustakaan dengan pendekatan dan metodologi ilmu sejarah.

\section{METODE}

Pada penelitian ini ingin mencoba untuk mengungkapkan bagaimana praktik kebijakan informasi dan propaganda program kolonisasi dan transmigrasi. Dalam pelaksanaan kebijakan 
informasi dan propaganda tersebut akan coba dilihat mengenai pengkategorian penyebaran informasi kolonisasi yang dilakukan dengan dua cara, yaitu penyebaran informasi propaganda yang bersifat langsung dan penyebaran informasi secara tidak langsung.

Pendekatan yang digunakan dalam penelitian ini adalah deskriptif yaitu mendeskripsikan sifat-sifat khas suatu proses sejarah dalam kurun waktu tertentu. Secara metode artikel penelitian ini terdiri atas berbagai tahapan sebagaimana cara kerja penelitian sejarah umumnya namun penekanan difokuskan pada aspek informasi-informasi yang terkandung dalam latar peristiwa dan waktu tersebut. Langkah awal adalah mengumpulkan berbagai sumber dari arsip dan sumber sezaman lainnya yang berhubungan dengan praktik informasi dalam rangka program kolonisasi pemerintahan Hindia Belanda.

Hal yang menjadi tantangan dari artikel jurnal ini adalah tidak memungkinkannya pengumpulan sumber lisan melalui wawancara mendalam dengan saksi atau pelaku kolonisasi. Sehingga upaya untuk mengatasi hal tersebut dimaksimalkan dengan memanfaatkan informasi dan fakta dari sumber-sumber primer yang ada di berbagai sumber arsip dan artikel koran yang terdapat di Arsip Nasional, Perpustakaan Nasional, dan penelusuran online. Metode berikutnya adalah tahapan interpretasi secara heuristik untuk menghindari bias melalui proses triangulasi antar berbagai sumber. Fakta dan interpretasi akan dijelaskan secara kritis reflektis. Sehingga proses interpretasi selalu diupayakan menjadi terkait dengan fakta-fakta yang ditemukan. Bersamaan dengan pengolahan sumber, penulisan yang bersifat kronologis.

Untuk meminimalisir bias dan mereduksi kemungkinan kesalahan dalam menginterpretasi data-data sumber penulis berupaya dengan melakukan pembacaan berhati-hati dan melakukan perbandingan-perbandingan berdasarkan sumber yang tersedia. Secara detail dan terus menerus artikel ini diupayakan untuk selalu fokus terarah pada pembahasan terkait konteks informasinya. Sebagai bentuk upaya dalam mendukung kajian ini disertakan pula beberapa gambar-gambar yang berguna untuk menerangkan situasi yang berlangsung.

\section{HASIL DAN PEMBAHASAN}

Berlandaskan politik etis tersebut maka pemerintah kolonial Belanda mengupayakan usaha pembukaan daerah perkebunan-perkebunan baru di luar pulau Jawa dan sekaligus dengan buruh taninya. Melalui program migrasi, di samping juga edukasi dan irigasi, pemerintah juga 
bermaksud untuk memindahkan sebagian penduduk Jawa, khususnya yang ada di Jawa Tengah ke luar Jawa, dengan pertimbangan lahan yang masih luas dan jarak yang relatif paling dekat ditentukanlah wilayah Distrik Lampung sebagai daerah tujuan. Pemindahan penduduk tersebut diujicobakan pada 1905 yang mana kemudian dikenal dengan kebijakan kolonisasi.

Dalam rangka menjalankan kebijakan kolonisasi tersebut, pemerintah Belanda juga mengupayakan suatu strategi informasi untuk mempropagandakan kebijakan kolonisasi pertanian tersebut. Hal ini mendapat porsi perhatian yang sangat besar dari Pemerintah Hindia Belanda. Kebijakan informasi tersebut muncul atas prakarsa dari Komisi Pusat (Centrale Commissie-Hindia Belanda). Melalui kebijakan tersebut pemerintah Hindia Belanda berupaya mempengaruhi penduduk-penduduk pribumi dengan intervensi yang dilakukan secara sistematis. Upaya ini memang tidaklah mudah, pemerintah Hindia Belanda ketika itu telah sadar dan sangat meyakini bahwa tidak akan sepenuhnya bisa meyakinkan orang Jawa untuk mau melakukan imigrasi meninggalkan tanah kelahiran yang sudah ditempati selama ini.

Ada beragam cara dan upaya intensif dalam konteks diseminasi informasi yang dilakukan pemerintah Hindia Belanda dan bahkan karena radikalnya sering disebut sebagai propaganda kolonisasi. Seperti sebagaimana yang disampaikan oleh Komisi Pusat, yang dirangkum dari berbagai literatur kesulitan untuk membujuk orang Jawa bergerak adalah, 'homogenitas' mereka, yaitu keterikatan mereka terhadap tempat kelahiran di tanah Jawa.

Program kolonisasi yang dimulai pada 1905 dengan tujuan utama yang sebenarnya juga tidak lepas dari kepentingan pemerintah Kolonial Belanda yaitu untuk mendapatkan tenaga kerja bagi perkebunan-perkebunan di Sumatera. Pada masa awal pelaksanaan karena dilatarbelakangi biaya tinggi dan dari hasil evaluasi pemerintah kolonial Belanda program ini dinilai hasilnya kurang memuaskan. Maka program kolonisasi ini pernah hampir dihentikan pada tahun 1928. Tetapi, memasuki tahun 1929 di Hindia Belanda pernah terjadi situasi kemerosotan ekonomi sehingga banyak sekali buruh di Jawa, bahkan jumlahnya hingga ribuan ketika itu yang dipecat. Hal ini memunculkan kekhawatiran di pemerintah Kolonial, bahwa dengan pemecatan para buruh tersebut dapat mengganggu keamanan dan stabilitas di Jawa. Maka dari itu pemerintah kolonial memutuskan untuk tetap melanjutkan program kolonisasi dengan mengirimkan mantan buruh-buruh tersebut ke luar pulau Jawa. 


\subsection{Bentuk Praktik Informasi Propaganda Program Kolonisasi}

Hakikat praktik informasi ini adalah untuk menumbuhkan dan menanamkan pengertian tentang potensi-potensi di daerah proyek kolonisasi. Tujuan utamanya adalah meningkatkan taraf hidup masyarakat sebagai bagian dari balas budi yang diberikan pemerintah Hindia Belanda walaupun belakangan juga ada alasan-alasan tersembunyi lain, seperti kepadatan pulau jawa, pemerataan produktifitas berbagai wilayah di nusantara dan suatu tujuan yang juga sangat masuk akal adalah penyedian dan distribusi tenaga kerja murah dalam rangka peningkatan kas pemerintah Belanda. Sehingga upaya untuk menumbuhkan daya tarik dan animo penduduk untuk mengikuti program kolonisasi ini diupayakan benar oleh pemerintah Belanda.

Pelaksanaan praktik informasi penerangan/penyuluhan dilaksanakan dengan berbagai cara, setidaknya ada dua bentuk yaitu, Auditif: ialah dengan mendatangi penduduk di daerah-daerah dengan memberikan penjelasan-penjelasan tentang situasi dan kondisi serta kehidupan sosial ekonomi di daerah asal, yang memungklnkan dapat menimbulkan daya dorong untuk berkolonisasi. Selain itu diberikan pula penjelasan-penjelasan tentang potensi dan situasi di daerah tujuan kolonisasi. Ada pula bentuk Visual, yaitu dengan jalan mengadakan pemutaran slide dan film, penyebaran brosur-brosur dan poster serta pertunjukan kesenian tradisi

\subsection{Praktik Informasi Propaganda Kolonisasi secara Langsung}

Disebutkan pula bahwa salah satu tugas terberat dari komisi pusat adalah meningkatkan jumlah orang Jawa yang mau berpindah ke luar Jawa. Setiap tahunnya, jumlah keluarga yang bisa membantu koloni baru terus mengalami peningkatan. Namun, pada kenyataanya jumlah orang Jawa yang bermigrasi tidak berubah seiring dengan pertambahan kemampuan penyerapan. Komisi telah terus menerus bekerja tanpa henti guna untuk merekrut anggota baru. Para calon yang akan direkrut secara sistematis didekati melalui propaganda informasi langsung dan tidak langsung.

Keadaan tersebut ternyata juga memaksa pemerintah Hindia Belanda untuk mengalokasikan dana yang besar untuk penyelenggaraan propaganda informasi. Misalnya, pada tahun 1940 pengeluaran dialokasikan dan terserap sebesar 4,2 persen dari total anggaran, sehingga rata-rata 7,40 gulden per keluarga. Dari hasil temuan hal ini menjadi begitu besar ada karena pada masa tersebut sebagian besar orang Jawa masih dalam kondisi buta huruf. Sehingga strategi kebijakan informasi yang diterapkan tidak bisa dilakukan hanya dilakukan melalui 
informasi yang berisi kata-kata yang dicetak saja. Secara kalkulatif jika masyarakat Jawa ketika itu bisa memahami informasi yang disebarkan melalui media cetak seperti koran, brosur dan pamflet tentu sudah dapat diperkirakan bahwa biaya yang dikeluarkan untuk propaganda relatif lebih murah.

Kondisi ini sangat sulit untuk diminimalisir. Berbagai cara alternatif coba diupayakan untuk mengurangi biaya tetapi tetap tidak banyak membawa hasil. Harapannya walaupun bagaimana bahwa media informasi berupa buklet dan alat bantu visual dapat menggambarkan kondisi "Tanah Sabrang" sehingga dengan seiring perkembangan waktu akan membiasakan pemuda desa dengan gagasan migrasi. Kemudian juga dorongan agar mereka siap untuk membangun rumah tangga sendiri, sehingga hal ini juga diharapkan akan mendorong mereka untuk lebih bersemangat dalam mengikuti program kolonisasi pemerintah Hindia Belanda.

Rata-rata kondisi petani Jawa ketika itu masih berfikiran sangat konservatif dan penuh kecemasan. Untuk membujuk dan memotivasi petani Jawa agar bersedia meninggalkan pulau asalnya tersebut, maka pemerintah Hindia Belanda disamping dengan penyebaran informasi tercetak juga berupaya melakukan pendekatan secara psikologis dan dengan cara menyampaikan informasi-informasi tentang program kolonisasi secara langsung guna meyakinkan target dan sasaran program. Untuk menjalankan tujuan ini, beberapa koloni yang berhasil, dengan berpakaian bagus, dan puas dengan kondisi kehidupannya dibawa kembali ke distrik asalnya bahkan dengan membawa sampel tanah, hasil pertanian yang banyak dan foto kehidupan di koloni.

Dari kenyataan tersebut sekiranya tidak berlebihan jika bukti-bukti berupa sampel tanah, hasil pertanian dan gaya hidup masyarakat yang memperlihatkan keberhasilan juga merupakan suatu bentuk dokumentasi yang memuat informasi yang dapat dipahami dan diterima masyarakat luas. Secara langsung atau tidak langsung hal tesebut juga semakin memperteguh keyakinan akan begitu luasnya spektrum informasi dan pengetahuan sesuai dengan konteks zamannya.

Dengan informasi-informasi konkret semacam itu, masyarakat jadi semakin mudah dan nyaman dalam menyampaikan berbagai ketakutan-ketakutan dan keluh kesah terhadap mantan penduduk desa yang sekaligus telah direkrut oleh pemerintah Hindia Belanda sebagai agen informasi yang bertugas untuk seluas-luasnya menyampaikan berbagai program kolonisasi yang diinisiasi oleh pemerintah. Kondisi tersebut sebagai suatu strategi kebijakan informasi juga turut 
membawa kemantapan bagi masyarakat untuk turut berpartisipasi dalam program kolonisasi pemerintah Hindia Belanda sebagai bagian dari implementasi politik etis.

Bahkan diseminasi informasi yang dilakukan para agen ini dapat digolongkan sebagai advance. Sebagai contoh para petani yang malu atau tidak berani mengajukan pertanyaan untuk mendapatkan informasi di dalam pertemuan-pertemuan majelis besar diberi kesempatan untuk mendapatkan informasi secara rahasia, bahkan mengobrol sembari menghisap rokok dan minum secangkir kopi secara santai. Para petani yang bertugas sebagai agen informasi dan melakukan propaganda sebagian besar juga didampingi oleh istrinya. Para istri ini juga turut berperan dalam menyampaikan informasi. Mereka akan turut mendiskusikan berbagai pengalamannya dengan wanita desa sehingga semakin memantapkan para suami dan istri calon kolonis. Kolonis yang dipilih sebagai propagandis oleh pejabat yang berwenang, juga diberi kebebasan untuk mengatur sendiri cara yang digunakan.

Melalui strategi penyebaran informasi tersebut upaya merekrut calon kolonisasi ini dari beberapa literatur ternyata akan semakin maksimal dan efektif ketika dilakukan saat mendekati tanggal keberangkatan yang dijadwalkan. Penerimaan informasi dan motivasi tersebut selalu bergerak dinamis naik turun. Pengalaman yang ada sudah membuktikan jika penyebaran informasi dilakukan karena dari jauh hari atau terlalu jauh sebelum keberangkatan, maka calon kolonis banyak yang berubah pikiran. Hal lain yang juga penting dalam perekrutan adalah memilih masa patcheclick (masa sulit) yaitu periode tahunan saat terjadinya kelangkaan pangan di Jawa. Maka penyebaran informasi itu sering dilakukan pada minggu-minggu terakhir sebelum masa panen.

Metode penyampaian informasi langsung lainnya yang turut dilakukan pada masa

pemerintahan Hindia Belanda ini adalah dengan mengirim penduduk desa Jawa untuk berkunjung ke koloni-koloni di luar Jawa yang dibiayai secara penuh oleh pemerintah. Hal ini juga efektif dengan biaya yang jugar relatif lebih murah dan efektif karena salah satu yang biasanya pimpinan desa tersebut melihat langsung kondisi di wilayah kolonisasi dan akan menyampaikan informasi-informasi yang diperolehnya kepada masyarakat desanya.

\subsection{Praktik Informasi Propaganda Kolonisasi secara Tidak Langsung}

Metode atau propaganda tidak langsung termasuk penyampaian informasi melalui slideslide yang disampaikan oleh para penyuluh profesional dan juga melalui pertunjukan teatrikal 
Jawa. Pada masa tersebut, bahkan hampir tidak ada stasiun kereta api, pegadaian, atau bangunan umum pemerintah Hindia Belanda di Jawa yang tidak menampilkan poster berwarna-warni yang berisi informasi-informasi yang bertujuan untuk memotivasi dan mengundang orang Jawa ke Tanah Sabrang.

Upaya yang juga dilakukan komisi secara terus-menerus untuk menjalankan deseminasi informasi kepada masyarakat adalah membagikan kepada orang Belanda serta pejabat Indonesia, kalender dinding bersisi ilustrasi gambar begitu indah yang menampilkan foto-foto pemandangan khas di wilayah-wilayah koloni dan buku memorabilia yang penuh dengan slogan dan fakta tentang kolonisasi. Buku-buku tersebut dicetak dalam dua edisi, yaitu dalam bahasa Melayu dan Belanda, komisi juga mengeluarkan buletin triwulanan yang memuat berbagai informasi mengenai kolonisasi.

Perhatian yang khusus juga diarahkan untuk mengenalkan generasi muda desa Jawa tentang gagasan migrasi, mengingat bahwa "anak muda yang memiliki masa depan."Komisi tersebut memberikan murid sekolah lanjutan desa (kelas empat dan lima) dengan buku teks di Tanah Sabrang. Setiap sekolah desa di Jawa Tengah dan Jawa Timur menerima reproduksi tiga lukisan yang menggambarkan lokasi kolonisasi, pembukaan hutan, dan pemandangan pasar di Gedongtataan (Distrik Lampung). Para pemukim terus-menerus didesak untuk tetap berhubungan dengan keluarga dan teman mereka, dengan kartu pos, kartu pos bergambar, perangko, dan, jika mereka buta huruf, dengan juru tulis, tanpa biaya.

Bahkan selama masa panen para kolonis juga didesak untuk mengirim amplop dengan sampel beras. Setiap bulan ribuan pesan ini dikirim ke desa-desa di Jawa. Menurut catatan komisi, pada tahun 1939 kolonis di Distrik Lampung mengirim 8.019 kartu pos, 1.842 surat, 428 amplop berisi beras, dan 12.246 foto ke Jawa. Banyaknya pesanan uang yang dikirim oleh pemukim kepada kerabat mereka di Jawa juga memiliki nilai informasi dan propaganda, sebagai bukti bahwa kondisi yang lebih baik terjadi di luar Jawa daripada di Jawa. Catatan menu njukkan bahwa koloni Jawa di Distrik Lampoeng mengirim 165.000 gulden ke Jawa selama tahun 1935 dan 15.000 gulden selama delapan bulan pertama tahun 1936.

Praktik informasi secara tidak langsung dan diperkirakan akan memberikan efek propaganda luar biasa ketika itu adalah melalui film. Kemudian dicetuskanlah inisiatif penggarapan film "Tanah Sabrang”. Sebuah bentuk strategi penyebaran informasi melalui gambar bergerak diperkirakan akan menarik minat masyarakat dalam jumlah yang besar dan 
ruang lingkup yang luas. Melalui gagasan dari C.J.J. Maassen, seorang penasihat masalahmasalah pertanian pemerintah kolonial, memberikan saran agar pemerintah Hindia Belanda memprakarsai pembuatan film propaganda kolonisasi. Optimisme tersebut muncul karena pada masa itu, film adalah sesuatu yang sangat baru bagi penduduk desa dan karena itu diharapkan akan menjadi medium penyebaran informasi dan menarik perhatian banyak orang.

Departemen Binnenlandsch-Bestuur (BB) melalui Centrale Commissie voor Emigratie en Kolonisatie van Inheemschen (Komisi Pusat untuk Migrasi dan Kolonisasi Pribumi), sebagai perpanjangan tangan pemerintah menerima usulan tersebut. A. Jonkers, seorang pejabat yang memang sudah memahami budaya dan kebiasaan masyarakat Jawa, menjadi penasihat sekaligus membuat naskah. Film "Tanah Sabrang, penggarapannya dipercayakan kepada Mannus Franken, seorang sineas kewarganegaraan Belanda yang telah terkenal akan pengalaman dan karir cemerlangnya di Hindia Belanda. Selain itu karya-karyanya dipandang mencerminkan kepedulian dan kecintaan terhadap negeri koloni beserta penduduknya.

Mannus Franken menjelaskan bahwa filmnya "Tanah Sabrang”, pertama-tama ditujukan kepada penduduk desa dan kaum tani, yang kemungkinan belum pernah sama sekali menonton film dan dapat menyerap pesan informasi secara utuh dari film (film intelek). Oleh karena itu muatan informasi yang dikisahkan di dalamnya dibuat dengan sesederhana mungkin agar mudah dipahami oleh masyarakat desa. Film ini menceritakan tentang rombongan masyarakat desa di Jawa (Tengah) yang bertekad pindah ke Tanah Sabrang setelah mereka yakin akan informasi dan penerangan yang diberikan oleh para pamong desa mereka termasuk bupatinya. Suatu harapan bahwa di tanah yang baru nanti kesempatan untuk mencapai kemakmuran akan terbuka secara luas.

Gambar-gambar pada film tersebut memuat informasi tentang semua tahapan migrasi, mulai dari tanah asal, wilayah kolonisasi, rumah, kebun, dan areal persawahan subur. Bahkan agar informasinya benar-benar dapat sampai pada masyarakat maka ditampilkan pula setting permainan wayang, melalui tiga tokoh Semar bersama putranya Petruk dan Gareng sebagai bagian hiburan tradisional Jawa dengan kebudayaan telah diakrabi masyarakat, walaupun tetap terselip informasi mengenai propaganda program kolonisasi. Informasi mengenai fakta-fakta bahwa orang Jawa bisa dan berkesempatan untuk mendapatkan kehidupan yang lebih baik dan lebih betah di negeri barunya. 
Tiga buah truk dengan proyektor dan sound system berkeliling di Jawa Tengah dan Jawa Timur. Daerah-daerah padat populasi penduduk seperti Sokaraja, Purbalingga, Banyumas, Kebumen, Gombong, Kutawinangun dan beberapa kota lainnya menjadi tujuan utama. Di putar pada lapangan dan areal terbuka yang ditonton bahkan sampai sekitar 80 ribu orang. Bahkan banyak yang menontonnya berkali-kali dan secara gratis. Dengan kekuatan persuasif film yang memiliki kesempatan untuk merangsang imajinasi dan motivasi masyarakat desa.

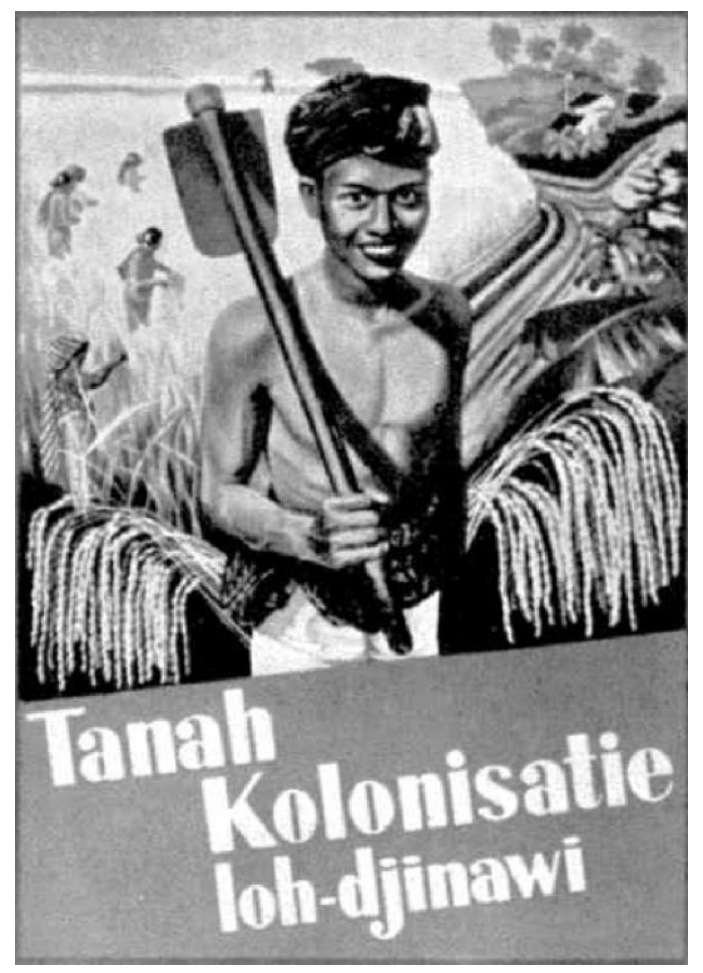

Gambar 1. Poster Penduduk di daerah Kolonisasi

Sumber: Arsip 'Het kolonisatieland vloeit over van vruchtbare sawah's'. Uit: Grasveld, Tanah Sabrang 


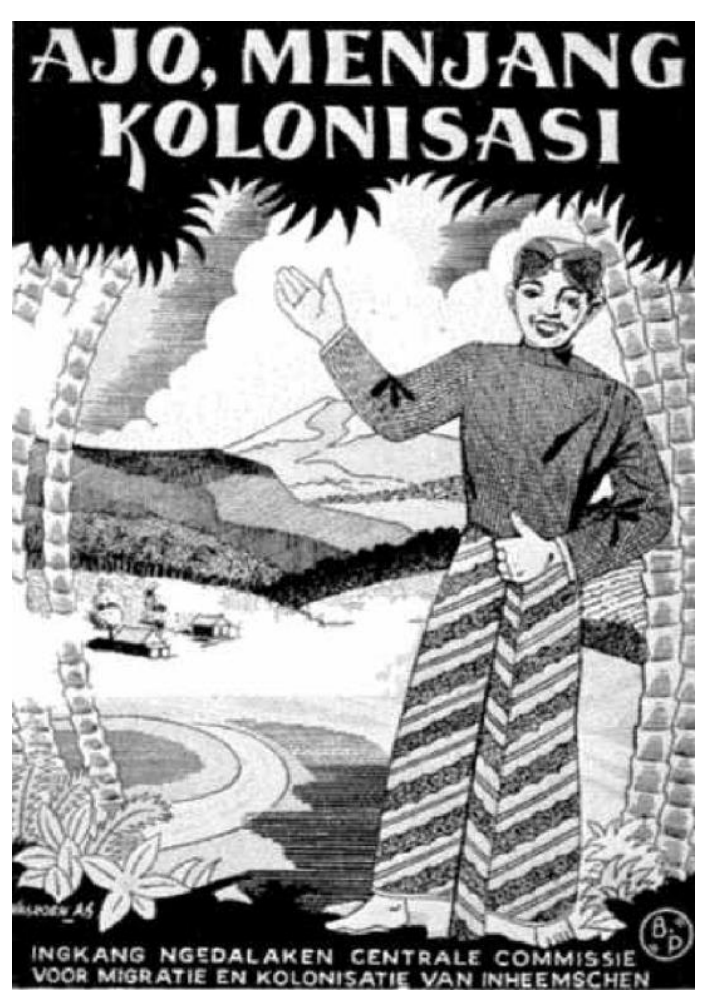

Gambar 2. Poster gambar ilustrasi ajakan dari Centrale Commissie untuk mengikuti program Kolonisasi

Sumber:Arsip Het beloofde land aan de overkant Grootschalige overheidsgestuurde emigratie en kolonisatie van Java naar Lampong, 1932-1941

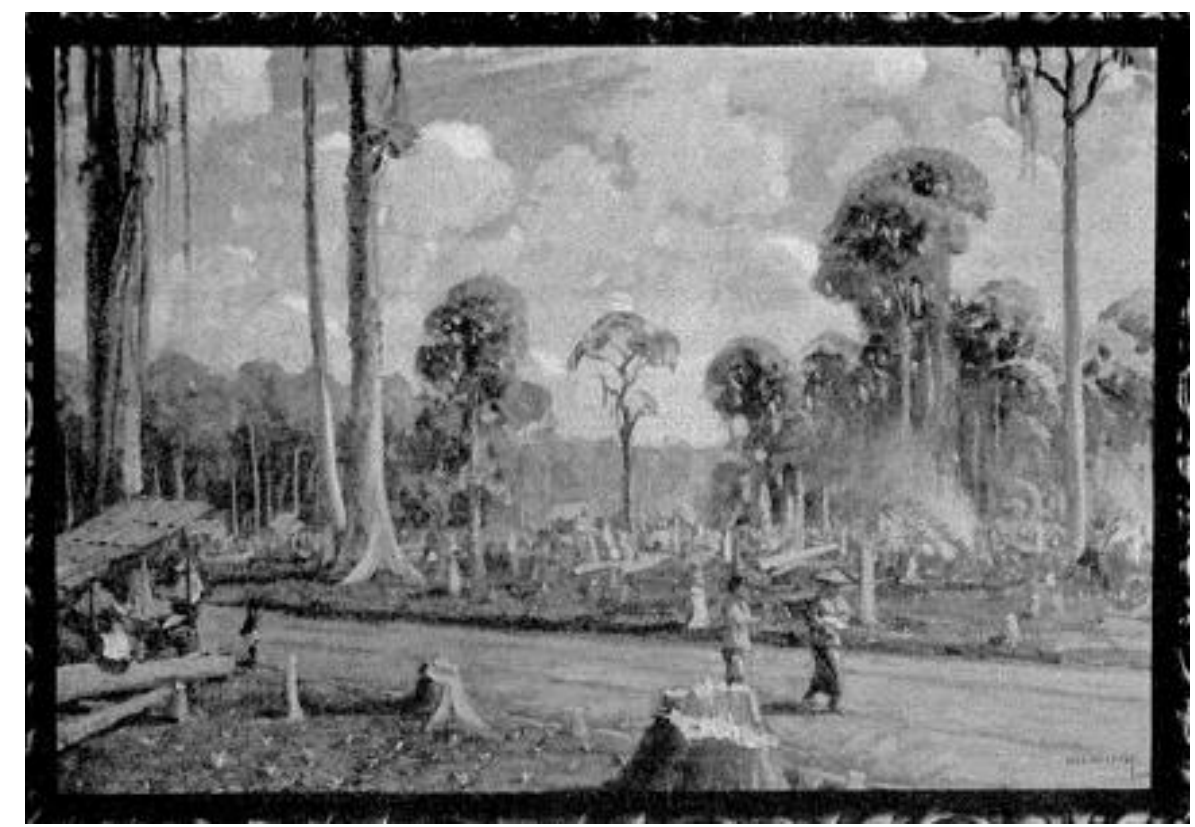

Gambar 3. Foto Ilustrasi wilayah Kolonisasi yang dicetak di kalender dan sampul buku Sumber: Arsip 'Openlegging. Naar een schilderij van H.A.L. Wichers.' Uit: Kolonisatie Bulletin Nr. 3. 


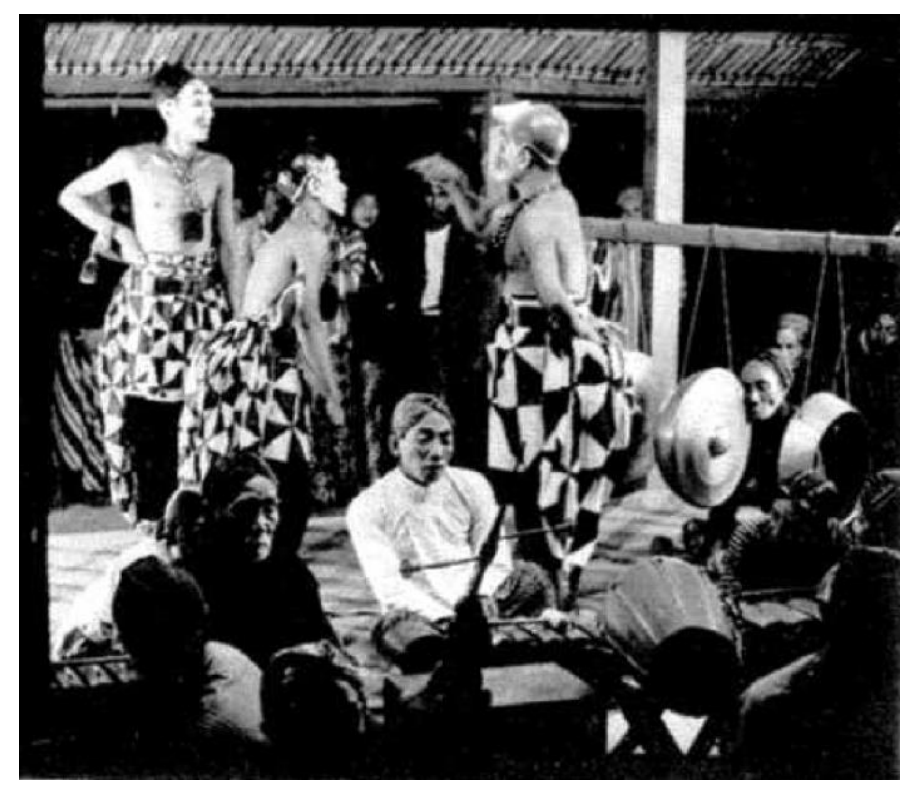

Gambar 4. Pertunjukan rakyat yang mengangkat tema tentang ajakan kolonisasi

Sumber:Arsip Het beloofde land aan de overkant Grootschalige overheidsgestuurde emigratie en kolonisatie van Java naar Lampong, 1932-1941 -- Film: Mannus Franken, 'Tanah Sabrang, het land aan de overkant' (1938). Naar scenario van A. Jonkers, camera: Jan B. van der Kolk.

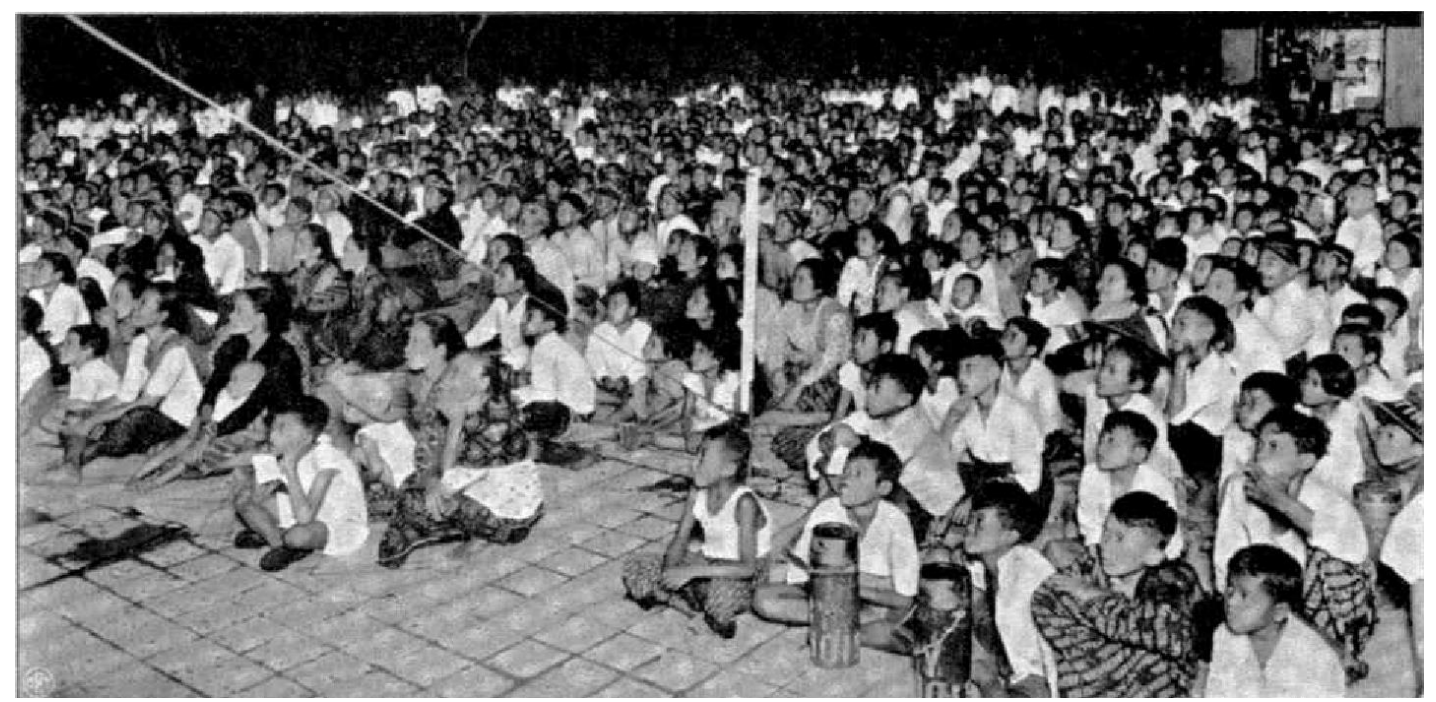

Gambar 5. Suasana saat pemutaran film dokumenter tentang program kolonisasi

Sumber: Arsip Het beloofde land aan de overkant Grootschalige overheidsgestuurde emigratie en kolonisatie van Java naar Lampong, 1932-1941

\section{KESIMPULAN}

Sarana atau media informasi propaganda Pemerintahan Hindia Belanda dalam rangka memaksimalkan pelaksanaan program kolonisasi dilakukan secara langsung dengan memanfaatkan agen agen kolonisasi. Cara lain yang juga ditempuh adalah dengan memanfaatkan berbagai sarana tercetak 
seperti brosur, pamflet dan bahkan film yang tempatkan dan putar pada ruang-ruang publik yang tersedia ketika itu. Dari beragam bentuk dan sarana informasi yang disediakan saat itu, momentum waktu penyampaian juga sangat berpengaruh signifikan dalam kesuksesannya. Semakin dekat atau gencar pengulangan penyampaian informasi dengan jadwal keberangkatan calon masyarakat yang akan diberangkatkan terbukti lebih baik dalam hal animo masyarakat untuk mengikuti program tersebut.

Praktik informasi dan propaganda yang dijalankan pemerintah Hindia Belanda dilakukan dalam mendukung program kolonisasi. Informasi dan propaganda yang dimaksud pada tulisan ini adalah beragam bentuk dan produk yang diterapkan Pemerintah Hindia Belanda. Kebijakan ini juga dapat berjalan secara maksimal karena di dalam penerapannya kebijakan ini memang ditangani secara khusus oleh Komisi Pusat (Centrale Commissie-Hindia Belanda) yang dibentuk dan diberi kewenangan oleh pemerintah Hindia Belanda dalam menjalankan kebijakan informasi dan propaganda tersebut. Dampak yang dihasilkan dari penerapan praktik informasi dan propaganda secara kuantitas dan kualitasnya dapat dikatakan cukup besar dan dapat dikategorikan sebagai inovasi yang telah melampaui zamannya. Di mana hal itu sangat dimungkinkan dan tidak dapat diulangi pada masa-masa setelahnya.

Propaganda dengan menggunakan film sangat besar pengaruhnya, bahkan informasi propaganda melalui film disinyalir memberikan hasil yang terbesar, melebihi bentuk-bentuk informasi propaganda lainnya. Bentuk penyebaran informasi melalui koran, masih sangat sulit karena masih banyak masyarakat yang buta huruf, informasi melalui radio juga terbatas karena banyak desa-desa atau dan masyarakat di gunung-gunung yang tidak mampu membeli radio. Melalui media poster, pamphlet dan media lainnya juga tidak banyak orang yang melihatnya. Film dengan alat-alatnya yang komplit yang dapat diringkas dalam satu mobil dengan mobilitas yang sangat leluasa, mulai dari kota, desa bahkan sampai di kaki gunung.

\section{DAFTAR PUSTAKA}

A. Jonkers, 'Het bevolkingsvraagstuk van Java en de landbouwkolonisatie'. Indonesië: tweemaandelijks tijdschrift gewijd aan het Indonesisch cultuurgebied Vol. 1 (1947) 28-42 en $150-161,156$.

Bijv. in De Indische courant, De Sumatra post en het Bataviaans Nieuwsblad stonden met name tussen 1937 en 1939 vaak nieuwsberichten over Javanenkolonisatie. De kolonist : 14 daagsch tijdschrift ter bevordering van de kolonisatie van Nederlanders binnen het rijksverband / Nationale Nieuw-Guinea vereeniging 1937-1938 (microfilm KIT)

Film Propaganda dalam Pertjatoeran Doenia dan Film, No. 9, 1 Februari 1942. 
Hardjono, J., (1989). The Indonesian transmigration program in historical perspective. International migration 26

Hardjono, J.M., (1977). Transmigration in Indonesia Kuala Lumpur

Heeren, H. J., (1967). Het land aan de overkant: transmigratie van Java naar Sumatra. Meppel

Heijting, H.G.,. (1938). 'De les van wortelvast Gedong-tatakan (Javanen-kolonisatie)', De Indische Gids Vol. 60

Hurwitz, J.,. (1955). Agricultural Resettlement of Javanese farmers in the Outer Islands of Indonesia before World War II. Cambridge

Javaansche kolonisten naar de Lampongs', De Indische Gids Vol. 59

Kasijanto, (1995). Wayang, Film dan Propaganda Kolonisasi, makalah dalam Kongres Studi Belanda, Fakultas Sastra, UI, Depok.

Kolonisatie bulletin / Centrale commissie voor migratie en kolonisatie van inheemschen 1938 1941 (microfilm KIT).

Kolonisatie Bulletin Nr. 1. 1.

Kolonisatie Bulletin Nr. 1. 3.

Kolonisatie Bulletin Nr. 5. (Batavia 1939) 27; Pelzer, Pioneer settlement.Kuneman, Jaarverslag van de Centrale Commissie, 10-11. Maassen, De Javaansche landbouwkolonisatie.

Mantra, I. B. (1985). Pengantar Studi Demografi. Yogyakarta: Nur Cahaya.

M.H.K. Franken, Membuat Film di Hindia Belanda" dalam Filmliga, Filmen In Indie 31 Januari 1935.

Pelzer, Karl J., 'Tanah Sabrang and Java's Population Problem', The Far Eastern Quarterly Vol. 5 Nr.2 (1946) 132-142

Soedigdo Hardjosoe darmo (1965). dalam Mantra, I. B. Pengantar Studi Demografi. Yogyakarta: Nur Cahaya.

Sri Ana Handayani. (1994). Transmigrasi di Indonesia dalam Perspektif Sejarah. Jember: Universitas Jember.

Oey, Mayling. (1980). The Transmigration Program in Indonesia. Makalah Seminar on Government Resettlement Programmes in Southeast Asia, Canberra: Australian National University, 7 October 1980, hlm. 2-3.

Zo bedroegen de kosten van de propaganda in het jaar 193880.000 gulden op de totale uitgaven van 1,4 miljoen gulden in dat jaar. Kolonisatie Bulletin Nr. 7 (Batavia 1939) 
Bibliotech : Jurnal Ilmu Perpustakaan dan Informasi, 4 (1) 2019 